THE MANAGEMENT OF EXPERTISE 


\section{THE MANAGEMENT OF EXPERTISE}

Edited by

Harry Scarbrough

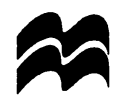

St. Martin's Press New York 
ISBN 978-0-333-56870-5 ISBN 978-1-349-24394-5 (eBook)

DOI 10.1007/978-1-349-24394-5

THE MANAGEMENT OF EXPERTISE

Selection, editorial matter, Introduction and Chapters 1, 6, 7 and 9 copyright (C) 1996 by Harry Scarbrough

Individual chapters (in order) (c) Gibson Burrell, Brian Baxter,

J. Martin Corbett, Jacky Swann, Lynn Ashburner and

Louise Fitzgerald 1996

Softcover reprint of the hardcover 1st edition 1996 978-0-230-01893-8

All rights reserved. No part of this book may be used or reproduced in any manner whatsoever without written permission except in the case of brief quotations embodied in critical articles or reviews.

For information, address:

St. Martin's Press, Scholarly and Reference Division, 175 Fifth Avenue, New York, N.Y. 10010

First published in the United States of America in 1996

ISBN 978-0-333-56870-5 (Cloth)

Library of Congress Cataloging-in-Publication Data

The management of expertise / edited by Harry Scarbrough.

p. $\mathrm{cm}$.

Includes bibliographical references and index.

ISBN 978-0-333-56870-5 (Cloth)

1. Personnel management. 2. Professional employees.

3. Organizational learning-Management. I. Scarbrough, Harry. 1955-

HF5549.M3132 1996

$658.3-\mathrm{dc} 20$ 


\section{Contents}

Preface

vii

Notes on the Contributors $\quad$ ix

Introduction $\quad 1$

Harry Scarbrough

$\begin{array}{lll}\text { Part } 1 \text { Societal perspectives on expertise } & 21\end{array}$

1 Understanding and managing expertise 23

Harry Scarbrough

2 Hard times for the salariat? $\quad 48$

Gibson Burrell

3 Consultancy expertise: a post-modern perspective 66

Brian Baxter

Part 2 Expertise and technological innovation

4 Designing jobs with advanced manufacturing technology: the negotiation of expertise

J. Martin Corbett

5 Professional associations and the management of expertise Jacky Swann

6 Strategic IT in financial services: the social construction of strategic knowledge Harry Scarbrough 


\section{vi Contents}

Part 3: Institutional change and the management of expertise

7 Information systems for knowledge management Harry Scarbrough

8 Beleaguered professionals: clinicians and institutional change in the NHS

Lynn Ashburner and Louise Fitzgerald

9 Commodifying professional expertise: IT in financial services Harry Scarbrough

Index 


\section{Preface}

'There's no grand design. People are just reaching out in the dark, touching hands' (A computer designer on the process of developing software - Kidder, 1981).

This book is 'reaching out in the dark' too. It addresses the nexus between wider patterns of industrial change and the deployment of expertise inside and outside organisations. Despite its escalating importance, the management of expertise is only now beginning to emerge as a topic in its own right out of the fragmented studies that currently typify the field. The latter are scatttered across a range of literatures including, variously, the management of professionals, the diffusion of innovations, the design of new technologies, and the development of corporate competences. Reframing these issues in terms of the management of expertise is not to deny the validity of these approaches, but rather to draw their cognate concerns into a sharper, unifying focus on expertise itself and the dynamics of its formation and deployment.

Doing this involves drawing on the work of a number of contributors, and it is worth saying a little about this book's composition of authors and chapters. Contrary to the usual sequence where teaching follows the text, this book actually developed out of a teaching programme - an eponymous option on the full time MBA programme at Warwick Business School. The programme afforded an opportunity to draw on the interests (and expertise) of a number of the faculty members at Warwick - Gibson Burrell, Martin Corbett, Louise Fitzgerald and Jacky Swan - to provide a sustained and integrated exploration of this topic. Moreover, the book, like the teaching programme, draws not only on the considerable research of the Warwick faculty, but also - through our wider networks of teaching and research contacts - on the valuable experience of Lynn Ashburner and Brian Baxter.

If the institutional logic behind this book is reasonably flexible and syncretic, so too is the intellectual logic that is outlined in its Introductory chapter and underpins its shape and structure. Partly this logic is counterpositional: to critique received wisdom on the management of experts or 


\section{viii Preface}

knowledge workers, and, more broadly, to question whether this focus is appropriate to the new mode of knowledge production that characterises the late twentieth century. Partly too, the logic is integrative: to make sense of the concurrent experience of a range of knowledge-based occupations whose management is being radically reshaped by institutional and technological change. The standard professional model of knowledge-based work is of limited value here. The fact, say, that these groups vary widely in their embodiment of the classical professional traits explains little of the commonality of experience posed by exposure to market forces, deregulation and organisational restructuring. In contrast, the focus on expertise developed here posits more fluid, contingent and less institutionally bounded social formations. This offers both an inclusive framework encompassing diverse localised applications of expert knowledge, and an account of the tendential conditions confronting knowledge-based occupations at large.

The dynamics of expertise increasingly transcend particular technological and structural circumstances to present broadly similar dilemmas to managers and organisations across a wide swathe of industrial settings. Sometimes these dilemmas take the form of innovation, sometimes resistance to change; sometimes they are merely functional trade-offs, at other times intensely political challenges to the status quo. Of course, this book can only provide a modest contribution to empirical studies of these differential effects. However its distinctive focus, coupled with the geometry of its constituent parts, helps to project a new and emergent horizon in understanding what it means to manage expertise.

\section{Reference}

Kidder, Tracy (1981) The Soul of a New Machine (New York: Avon). 


\section{Notes on the contributors}

Lynn Ashburner, formerly of the Centre for Corporate Strategy and Change, Warwick Business School, is a Lecturer in the Department of Management and Finance at the University of Nottingham. Her practical experience includes organisation development roles at Pilkington Brothers. Latterly her research interests have focused on large-scale change processes in UK hospitals, and the broader issues of professionalism and work organisation.

Brian Baxter is a Director of Kiddy \& Partners, a UK-based firm of management consultants and organisational psychologists. He received his first degree in psychology at Edinburgh University, and his $\mathrm{PhD}$ from the Department of Behaviour in Organisations, Lancaster University. Since the late 1970s he has worked as management consultant and manager, initially with Arthur Andersen and the W.S. Atkins Group. His assignments have covered strategic reorganisation, business reviews and reorientation activities, organisation development and managing change. His current interests are in the area of helping organisations to develop a post-modern outlook on their approaches to business life. He is also a Visiting Fellow at Lancaster University.

Gibson Burrell was formerly in the Department of Behaviour in Organizations at the University of Lancaster and is now Associate Chair (Academic Development) at Warwick Business School. He is currently interested in fin de siècle thinking in the area of management.

J. Martin Corbett is Senior Lecturer in Industrial Relations and Organisational Behaviour at Warwick Business School. His current research interests include the psychology of working with smart machines and the design of humancentred manufacturing systems. He has written a number of books, the most recent of which - Critical Cases in Organisational Behaviour - also features in the 'Management, Work and Organisations' series. 


\section{$\mathrm{x}$ Notes on the contributors}

Louise Fitzgerald is Senior Lecturer in Organizational Development, Warwick Business School. Her research and consultancy interests are focused on the management of change and restructuring in the UK National Health Service. Work with colleagues at Warwick's Centre for Corporate Strategy and Change has produced a number of papers and books on these topics, the most recent being The New Public Management in Action (in press).

Harry Scarbrough is a Lecturer in Industrial Relations and Organizational Behaviour, Warwick Business School. He has written and researched extensively on the organisational implications of IT, including Technology and Organization: Power, Meaning and Design (with J. Martin Corbett). His current interests are focused on the management of so-called 'knowledge assets' in organisational contexts.

Jacky Swan is a chartered psychologist, formerly of Aston University and currently Lecturer in Industrial Relations and Organisational Behaviour, Warwick Business School. Her research interests and publications focus on cross-national differences in the roles of professional associations in technology design and diffusion, and on the managerial cognitions in decisions about new technology. She is currently principal researcher on an ESRC project investigating the impact of European professional associations for production control on the diffusion of technology. 